\title{
Correlation of Maternal KIR and Parental HLA-C Genes Diversity With Risk of Preeclampsia in Lorestan Province of Iran
}

\author{
Soheila Akbari ${ }^{1}$, Seyyed Amir Yasin Ahmadi², Farhad Shahsavar ${ }^{3 *}{ }^{\mathbb{D}}$, Khatereh Anbari ${ }^{4}$
}

\begin{abstract}
Objectives: Fetomaternal immune tolerance induced by natural killer cells (NKs) is a necessary phenomenon associated with maternal killer-cell immunoglobulin-like receptors (KIRs) and fetal human leukocyte antigens (HLAs). We aimed to investigate maternal KIR, parental HLA-C, and maternal-parental KIR-HLA combination in 2 preeclampsia and control groups.

Materials and Methods: A total of 200 couples participated in this case-control study. DNA samples were assayed through polymerase chain reaction with sequence specific primers (PCR-SSP).

Results: No significant difference was observed between the cases and the controls regarding the maternal KIR genes and genotypes and paternal HLA-C genes. A significant relation was found for maternal KIR and paternal HLA-C combination. The relation was for the inhibitory combination KIR2DL1+HLA-C2 in the preeclampsia group $(P<0.05$; odds ratio $[\mathrm{OR}]=2.02$; sensitivity $=79 \%)$. In addition, maternal $A A$ genotype of KIR in combination with paternal $H L A-C 1 C 2$ was a risk factor $(P<00.05 ; O R=3.24$; specificity $=92 \%)$.

Conclusions: The inhibitory maternal-paternal combinations KIR2DL1+HLA-C2 and $A A+H L A-C 1 C 2$ seem to be more associated with risk of preeclampsia. Prediction of the risk of preeclampsia with the help of maternal KIR typing and paternal $H L A-C$ typing can be possible in future.

Keywords: HLA-C, KIR, NK cells, Preeclampsia
\end{abstract}

\section{Introduction}

Preeclampsia is a pregnancy specific syndrome occurring in 3\%-14\% of all pregnancies worldwide based on recent reports (1). There are a variety of approaches to its pathogenesis. Among these approaches, immune system and its involved molecules are notable (2). The fascinating feature of immune system is that it does not normally reject the semi-allograft fetus. Two roles can be considered for immune system in implantation and pregnancy; the first one is impeding the formation of abnormal embryos, and the second one is maintenance of the fetomaternal interaction through immune tolerance signals.

Natural killer-cells (NKs) are the most important cells in the immune tolerance. The NKs identify self-cells through their killer-cell immunoglobulin-like receptors (KIRs) expressed on their surface. These KIRs interact with the human leukocyte antigens (HLAs) expressed on surface of nuclear self-cells. KIR has 8 inhibitory (2DL1, 2DL2, 2DL3, 2DL4, 2DL5, 3DL1,3DL2 and 3DL3) and 6 activating (2DS1, 2DS2, 2DS3, 2DS4, 2DS5 and 3DS1) genes. In human genome, both $H L A$ and KIR have loci (not locus) and therefore they are inherited as haplotypes. As well, each gene of their loci can be polymorphic. Hence interactions of different KIRs with different HLAs lead to different outcomes. Therefore from an anthropological point of view, people of ethnicities have different KIR-HLA interactions (3-7). There are 2 classes of HLA, I and II, and class I can be classical or non-classical. HLA-G is a nonclassical HLA expressed on the semi-allograft embryonic cells. This HLA interacts with KIR2DL4 molecules and triggers the immune tolerance (8-13). NKs might have (or not) the marker CD16 which is a weapon for antibodydependent cell-mediated cytotoxicity (ADCC). Usually $\mathrm{CD}^{2} 6^{\mathrm{dim}} \mathrm{NKs}$ are $\mathrm{CD} 16^{+}$; therefor $\mathrm{CD} 16^{+} \mathrm{CD} 56^{\text {dim }} \mathrm{NKs}$ are called cytotoxic NKs. On the other hand, CD16 CD56 ${ }^{\text {bright }}$ NKs are called immune-regulatory NKs $(2,14-16)$. About $90 \%$ of uterine NKs (UNKs) are immune-regulatory. Hence UNKs are not usually cytotoxic for embryo $(2,15)$.

The fascinating point is that how the immune system is both killing and protective. In other words, this system is a bodyguard to protect the self and kill the non-self. Pregnancy is a semi-allograft transplantation. Thus there

Received 21 October 2017, Accepted 1 February 2018, Available online 19 February 2018

${ }^{1}$ Department of Obstetrics and Gynecology, Lorestan University of Medical Sciences, Khorramabad, Iran. ${ }^{2}$ Pediatric Growth and Development Research Center, Institute of Endocrinology and Metabolism, Iran University of Medical Sciences, Tehran, Iran. ${ }^{3}$ Department of Immunology, Lorestan University of Medical Sciences, Khorramabad, Iran. ${ }^{4}$ Social Determinants of Health Research Center, Lorestan University of Medical Sciences, Khorramabad, Iran.

*Corresponding Author: Farhad Shahsavar, Email: shahsavarfarhad@yahoo.com 
is a question that "what is the action of immune system in such conditions; protection or rejection of the graft". The best answer for the above question is immune tolerance (2, $17,18)$. Of course immune tolerance is not the only reason for acceptance of this graft, because adhesive molecules like selectins (2) and integrins (19) are also important in early implantation. Such molecules and cytokines are produced by immune cells.

Since the involved NKs in placenta are maternal and on the other hand half part of the involved fetal HLAs are paternally originated, in the current study we intended to investigate maternal KIR genes and genotypes, maternal and paternal $H L A-C$, and maternal-paternal $K I R+H L A-C$ interactions in both preeclampsia and control groups. As a hypothesis, the inhibitory interactions can be more associated with preeclampsia, because of lower activity of the NKs having a high capacity of cytokines, angiogentic and adhesive molecules.

\section{Materials and Methods}

Subjects

For the present case-control study, a number of 100 couples were included in each group (totally 400 individuals). The inclusion criterion for the case group was having history of idiopathic preeclampsia (blood pressure $>140 / 90 \mathrm{~mm} \mathrm{Hg}$ after 20 weeks of gestation and proteinuria $>300 \mathrm{mg} / 24 \mathrm{~h}$ (20)), and the exclusion criterion was history of pregnancy complications other than preeclampsia, or history of any hormonal or genetic problems. The criteria for the control group were history of 2 successful deliveries and absence of any pregnancy complication. The patients were included in the study through convenient sampling across those who were referred to Asalian hospital of Obstetrics and Gynecology, Khorramabad, west of Iran, for fertility consult. The ethnicities of the patients were Lur (21) and Lak (22) from Lorestan province, Iran.

\section{Genetic Assay}

Genomic DNA was extracted from peripheral blood leukocytes $(2 \mathrm{~mL})$ using the EXTRA GENE I kit (BAG, Lich, Germany). DNA samples were genotyped using polymerase chain reaction with sequence specific primers (PCR-SSP) (23). For the presence or absence of KIR genes, we used KIR TYPE kit (BAG, Lich, Germany) and for genotyping their HLA-C ligands (HLA-C1, C2), we used EPI-TOP TYPE kit (BAG, Lich, Germany). These kits have been previously controlled and evaluated by their companies and also by some researchers (24). The frequencies of HLA and KIR genes were calculated through direct counting. Assessment of other types of non-classical HLAs like HLA-G was of the limitations of our study.

\section{Statistical Analysis}

The significance of associations was determined using the $\chi^{2}$ test with Yate correction and degree of freedom $(d f)=1$.
Significance level and CI were considered as 0.05 and 95\%, respectively. Bonferroni's correction was used for multiple comparisons. For each significant relation, the sensitivities, specificities and positive predicting values (PPVs) were calculated for medical diagnosis and prediction aims. Since the study was not cohort, conventional calculation of PPV would not be valid. Hence we used the corrected formula based on disease prevalence (25). In the case of ours, the prevalence of preeclampsia was $5 \%$ based on a meta-analysis (26). The CI of the medical diagnosis accuracy amounts were calculated through the formula $[1.96 \times \sqrt{ }[\mathrm{P}(1-\mathrm{P}) / \mathrm{n}]$. For $\mathrm{CI}$ calculation of $\mathrm{PPV}, \mathrm{P}=5 \%$ was considered based on the real prevalence of preeclampsia in Iran, and for CI calculation of sensitivity and specificity $\mathrm{P}=50 \%$ was considered.

\section{Results}

Among maternal KIR genes, no significant difference was observed between the cases and the controls after adjusting Bonferroni correction (Table 1). In addition, there was observed no significant relationship for maternal KIR genotypes (Figure 1). Many of these genotypes have been previously reported in Iranian and Lur populations (21). Among maternal HLA-C genes and genotypes,

Table 1. Distribution of Maternal KIR Genes and Genotypes in the Couples With Preeclampsia and Healthy Couples

\begin{tabular}{|c|c|c|}
\hline $\begin{array}{l}\text { Maternal KIR Genes } \\
\text { and Genotypes }\end{array}$ & $\begin{array}{c}\text { Couples With } \\
\text { Preeclampsia }(n=100) \\
\text { No. }(\%)\end{array}$ & $\begin{array}{l}\text { Healthy Couples } \\
(n=100) \\
\text { No. }(\%)\end{array}$ \\
\hline \multicolumn{3}{|l|}{ KIR genes } \\
\hline \multicolumn{3}{|l|}{ Inhibitory } \\
\hline 2DL1 & $96 *$ & 85 \\
\hline 2DL2 & 51 & 59 \\
\hline 2DL3 & 86 & 77 \\
\hline 2DL4 & 100 & 100 \\
\hline 2DL5A & 41 & 39 \\
\hline 2DL5B & 40 & 37 \\
\hline 3DL1 & 95 & 94 \\
\hline 3DL2 & 100 & 100 \\
\hline 3DL3 & 100 & 100 \\
\hline \multicolumn{3}{|l|}{ Activating } \\
\hline 2DS1 & 40 & 42 \\
\hline 2DS2 & 54 & 57 \\
\hline $2 \mathrm{DS} 3$ & 35 & 34 \\
\hline 2DS4 & 95 & 94 \\
\hline 2DS4-full & 34 & 34 \\
\hline 2DS4-del & 85 & 83 \\
\hline 2DS5 & 36 & 36 \\
\hline 3DS1 & 43 & 37 \\
\hline \multicolumn{3}{|l|}{ Pseudogenes } \\
\hline 2DP1 & $96 *$ & 85 \\
\hline 3DP1-full & 34 & 32 \\
\hline 3DP1-del & 96 & 96 \\
\hline \multicolumn{3}{|l|}{ KIR genotypes } \\
\hline $\mathrm{AA}$ & 32 & 28 \\
\hline$B x(A B+B B)$ & 68 & 72 \\
\hline
\end{tabular}




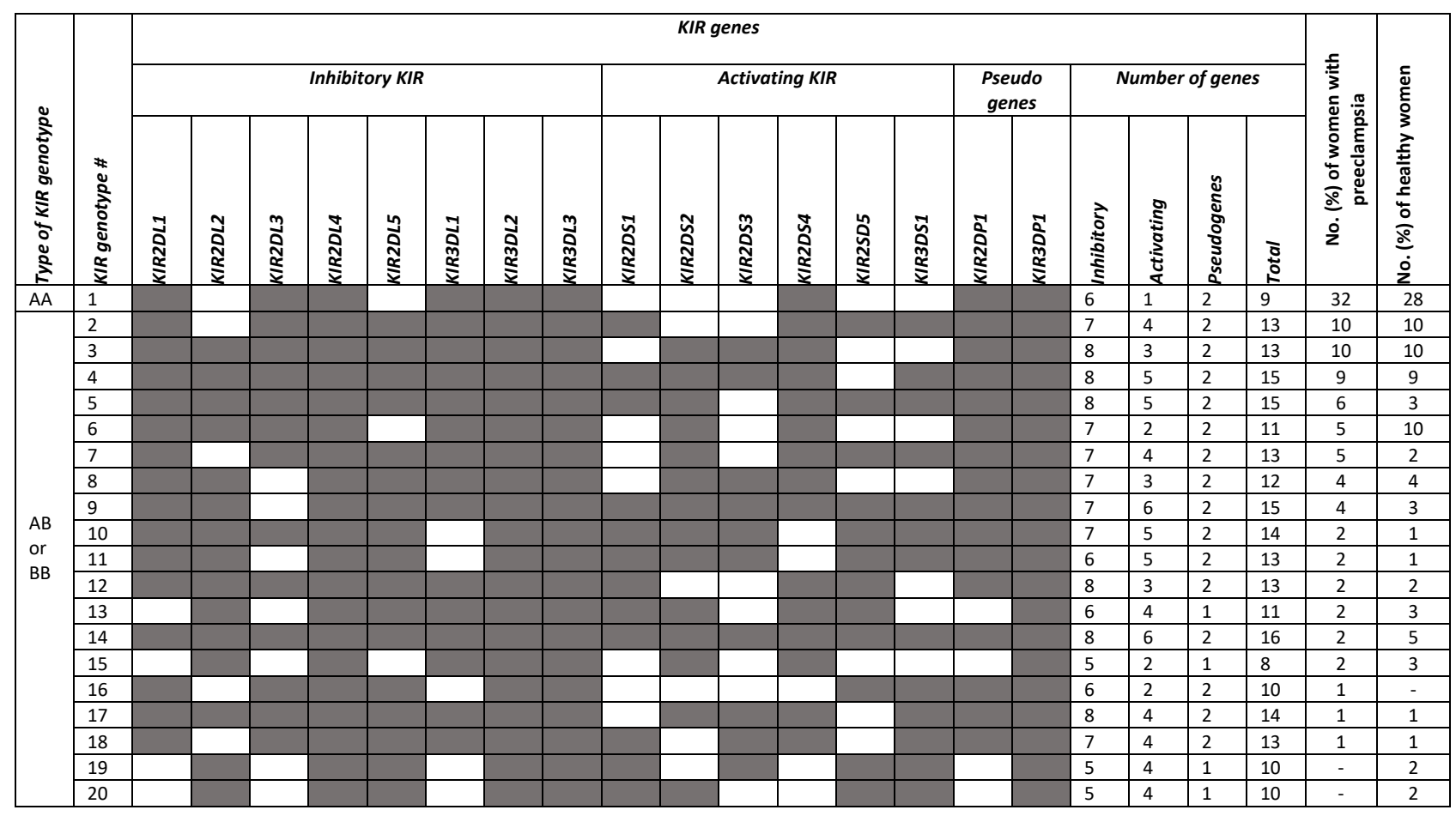

Figure 1. Distribution of KIR Genotypes in Women With Preeclampsia and Healthy Women. The grey rectangles indicate gene presence and the white rectangles indicate gene absence. Many of these genotypes have been previously reported in Iranian and Lur populations. No statistical relation was found.

HLA-C1 was a significant protecting factor $(P<0.05$; odds ratio $[\mathrm{OR}]=0.44)($ Table 2$)$. The same result was found for maternal KIR2DL2/3+HLA-C1 combination, because all the patients had at least one of these 2 KIRs (Table 3). Paternal HLA-C genes and genotypes were not significantly different between the cases and the controls (Table 4).

As we had hypothesized, a significant relation was found for a maternal KIR and paternal $H L A-C$ combination. The relation was for the inhibitory combination

Table 2. Distribution of Maternal HLA Ligand Genes in the Couples With Preeclampsia and Healthy Couples

\begin{tabular}{|c|c|c|c|c|}
\hline $\begin{array}{l}\text { Maternal HLA Ligand and } \\
\text { Genotypes }\end{array}$ & $\begin{array}{l}\text { Couples With Preeclampsia }(n=100) \\
\text { No. (\%) }\end{array}$ & $\begin{array}{l}\text { Healthy Couples }(n=100) \\
\text { No. (\%) }\end{array}$ & $\begin{array}{c}P \text { Value } \\
\text { (Yate Correction) }\end{array}$ & OR (Cl) \\
\hline \multicolumn{5}{|l|}{ HLA Ligand genes } \\
\hline $\mathrm{C} 1$ & 67 & 82 & $0.0231 *$ & $0.44(0.23-0.86)$ \\
\hline $\mathrm{C} 2$ & 78 & 68 & $\mathrm{NS}^{\mathrm{a}}$ & $N A^{b}$ \\
\hline \multicolumn{5}{|l|}{ HLA Ligand genotypes } \\
\hline $\mathrm{C} 1$ or $\mathrm{C} 2$ & 55 & 50 & NS & NA \\
\hline $\mathrm{C} 1$ and $\mathrm{C} 2$ & 45 & 50 & NS & NA \\
\hline
\end{tabular}

${ }^{*}$ Significant at $P<0.05 .{ }^{\text {a } N S: ~ n o n-s i g n i f i c a n t . ~}{ }^{\mathrm{b}} \mathrm{NA}$ : not applicable.

Table 3. Distribution of Maternal KIR+HLA Combinations in the Couples With Preeclampsia and Healthy Couples

\begin{tabular}{|c|c|c|c|c|}
\hline $\begin{array}{l}\text { Maternal HLA Ligand and } \\
\text { Genotypes }\end{array}$ & $\begin{array}{l}\text { Couples With Preeclampsia }(n=100) \\
\text { No. }(\%)\end{array}$ & $\begin{array}{l}\text { Healthy Couples }(n=100) \\
\text { No. (\%) }\end{array}$ & $\begin{array}{c}P \text { Value } \\
\text { (Yate Correction) }\end{array}$ & $\mathrm{OR}(\mathrm{Cl})$ \\
\hline \multicolumn{5}{|l|}{ HLA Ligand genes } \\
\hline $2 \mathrm{DL} 2 / 3+\mathrm{C} 1$ & 67 & 82 & $0.0231^{*}$ & $0.44(0.23-0.86)$ \\
\hline $2 \mathrm{DL} 1+\mathrm{C} 2$ & 74 & 64 & $N S^{a}$ & $N A^{b}$ \\
\hline \multicolumn{5}{|l|}{ Activating Combinations } \\
\hline $2 \mathrm{DS} 2+\mathrm{C} 1$ & 41 & 43 & NS & NA \\
\hline $2 \mathrm{DS} 1+\mathrm{C} 2$ & 29 & 32 & NS & NA \\
\hline
\end{tabular}

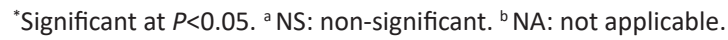


Table 4. Distribution of Paternal HLA Ligand Genes in the Couples With Preeclampsia and Healthy Couples

\begin{tabular}{lccc}
\hline $\begin{array}{l}\text { Paternal HLA Ligand and } \\
\text { Genotypes }\end{array}$ & $\begin{array}{c}\text { Couples With Preeclampsia (n=100) } \\
\text { No. (\%) }\end{array}$ & $\begin{array}{c}\text { Healthy Couples (n=100) } \\
\text { No. (\%) }\end{array}$ & $\begin{array}{c}P \text { Value } \\
\text { (Yate Correction) }\end{array}$ \\
\hline $\begin{array}{l}\text { HLA Ligand genes } \\
\text { O1 }\end{array}$ & 74 & 72 & NS $^{\mathrm{a}}$ \\
C2 & 79 & 76 & NS \\
HLA Ligand genotypes & & 52 & NA \\
C1 or C2 & 47 & NA & NS \\
C1 and C2 & 53 & 48 & NA \\
\hline
\end{tabular}

${ }^{a}$ NS: non-significant. ${ }^{b} \mathrm{NA}$ : not applicable.

Table 5. Distribution of Maternal KIR + Paternal HLA Combinations in the Couples With Preeclampsia and Healthy Couples

\begin{tabular}{|c|c|c|c|c|}
\hline $\begin{array}{l}\text { Maternal KIR+Paternal HLA } \\
\text { Combinations }\end{array}$ & $\begin{array}{l}\text { Couples With Preeclampsia }(n=100) \\
\text { No. (\%) }\end{array}$ & $\begin{array}{l}\text { Healthy Couples }(n=100) \\
\text { No. (\%) }\end{array}$ & $\begin{array}{c}P \text { Value } \\
\text { (Yate Correction) }\end{array}$ & OR (Cl) \\
\hline \multicolumn{5}{|l|}{ Inhibitory Combinations } \\
\hline $2 \mathrm{DL} 2 / 3+\mathrm{C} 1$ & 74 & 72 & $N S^{a}$ & $N A^{b}$ \\
\hline $2 \mathrm{DL} 1+\mathrm{C} 2$ & 79 & 65 & $0.0406^{*}$ & $2.02(1.07-3.81)$ \\
\hline \multicolumn{5}{|l|}{ Activating Combinations } \\
\hline $2 \mathrm{DS} 2+\mathrm{C} 1$ & 42 & 47 & NS & NA \\
\hline $2 \mathrm{DS} 1+\mathrm{C} 2$ & 28 & 34 & NS & NA \\
\hline
\end{tabular}

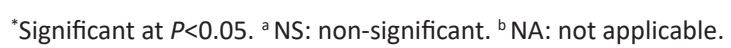

KIR2DL1+HLA-C2 in the preeclampsia group $(P<0.05$; $\mathrm{OR}=2.02$ ) (Table 5). Another interesting finding of ours was that maternal homozygote genotypes of $H L A-C$ in combination with paternal heterozygote genotype of $H L A-C$ was a risk factor $(P<0.05 ; \mathrm{OR}=2.25)$ (Table 6). The maternal and paternal genotypes of $H L A-C$ are shown in Tables 7 and 8. No significant relation was found for maternal KIR+HLA combinations (Table 9). In addition, maternal KIR AA genotype in combination with paternal $H L A$ heterozygote was a risk factor $(P<0.05$; OR $=3.24)$
(Table 10). Medical diagnosis accuracy components (sensitivity, specificity and PPV) are shown in Table 11.

\section{Discussion}

This case-control study aimed to investigate maternal $K I R$, and both maternal and paternal $H L A-C$ genes in preeclamptic and healthy couples in order to find a sensitive and specific method for prediction of preeclampsia (cohort approach) before marriage. As we hypothesized, the inhibitory interactions could be more

Table 6. Distribution of Parental HLA Ligand Genotypes in the Couples With Preeclampsia and Healthy Couples

\begin{tabular}{lcccc}
\hline $\begin{array}{l}\text { Maternal HLA Ligand } \\
\text { Genotypes }\end{array}$ & $\begin{array}{c}\text { Paternal HLA Ligand } \\
\text { Genotypes }\end{array}$ & $\begin{array}{c}\text { Couples With } \\
\text { Preeclampsia (n=100) } \\
\text { No. (\%) }\end{array}$ & $\begin{array}{c}\text { Healthy Couples } \\
\text { (n=100) } \\
\text { No. (\%) }\end{array}$ & $\begin{array}{c}P \text { Value } \\
\text { OR (CI) } \\
\text { (Yate Correction) }\end{array}$ \\
\hline C1 or C2 or & C1 or C2 & 25 & 34 & NS \\
C1 and C2 & C1 and C2 & 30 & 16 & $0.0289 *$ \\
C1 and C2 & C1 or C2 & 22 & 32 & NS \\
\hline
\end{tabular}

*Significant at $P<0.05 .{ }^{\text {a }} \mathrm{NS}$ : non-significant. ${ }^{\mathrm{b}} \mathrm{NA}$ : not applicable.

Table 7. Distribution of Maternal HLA Ligand Genes in the Couples With Preeclampsia and Healthy Couples

\begin{tabular}{|c|c|c|c|c|c|c|}
\hline $\begin{array}{l}\text { Maternal HLA } \\
\text { Ligand Genotypes }\end{array}$ & HLA-C1 & HLA-C2 & $\begin{array}{c}\text { Couples With } \\
\text { Preeclampsia }(n=100) \\
\text { No. }(\%)\end{array}$ & $\begin{array}{l}\text { Healthy Couples } \\
(n=100) \\
\text { No. }(\%)\end{array}$ & $\begin{array}{c}P \text { Value (Yate } \\
\text { Correction) }\end{array}$ & OR (CI) \\
\hline 1 (C1C1) & & & 22 & 32 & NS & NA \\
\hline $2(\mathrm{C} 2 \mathrm{C} 2)$ & & & 33 & 18 & $0.0231 *$ & $2.2(1.16-4.33)$ \\
\hline $3(\mathrm{C} 1 \mathrm{C} 2)$ & & & 45 & 50 & NS & NA \\
\hline
\end{tabular}

${ }^{*}$ Significant at $P<0.05 .{ }^{\text {a }} \mathrm{NS}$ : non-significant. ${ }^{\mathrm{b}} \mathrm{NA}$ : not applicable. 
Table 8. Distribution of Paternal HLA Ligand Genes in the Couples With Preeclampsia and Healthy Couples

\begin{tabular}{|c|c|c|c|c|c|c|}
\hline $\begin{array}{l}\text { Paternal HLA Ligand } \\
\text { Genotypes }\end{array}$ & HLA-C1 & HLA-C2 & $\begin{array}{c}\text { Couples With } \\
\text { Preeclampsia }(n=100) \\
\text { No. (\%) }\end{array}$ & $\begin{array}{l}\text { Healthy Couples } \\
\qquad \begin{array}{c}(n=100) \\
\text { No. }(\%)\end{array}\end{array}$ & $\begin{array}{l}P \text { Value (Yate } \\
\text { Correction) }\end{array}$ & OR (Cl) \\
\hline 1 (C1C1) & & & 20 & 31 & NS & NA \\
\hline $2(\mathrm{C} 2 \mathrm{C} 2)$ & & & 27 & 21 & NS & NA \\
\hline 3 (C1C2) & & & 53 & 48 & NS & NA \\
\hline
\end{tabular}

${ }^{a}$ NS: non-significant. ${ }^{b} \mathrm{NA}$ : not applicable.

Table 9. Distribution of Maternal KIR and HLA-C Genotypes

\begin{tabular}{|c|c|c|c|c|c|}
\hline KIR Genotype & HLA-C Genotype & $\begin{array}{l}\text { Couples With Preeclampsia }(n=100) \\
\text { No. }(\%)\end{array}$ & $\begin{array}{l}\text { Healthy Couples }(n=100) \\
\text { No. }(\%)\end{array}$ & $\begin{array}{l}P \text { Value (Yate } \\
\text { Correction) }\end{array}$ & OR (Cl) \\
\hline \multirow[t]{2}{*}{ AA } & $\mathrm{C} 1$ or $\mathrm{C} 2$ & 20 & 13 & NS & NA \\
\hline & $\mathrm{C} 1$ and $\mathrm{C} 2$ & 12 & 15 & NS & NA \\
\hline \multirow[t]{2}{*}{$\mathrm{AB}$ or $\mathrm{BB}$} & $\mathrm{C} 1$ or $\mathrm{C} 2$ & 35 & 37 & NS & NA \\
\hline & $\mathrm{C} 1$ and $\mathrm{C} 2$ & 33 & 35 & NS & $\mathrm{NA}$ \\
\hline
\end{tabular}

a NS: non-significant. ${ }^{\text {b } N A: ~ n o t ~ a p p l i c a b l e . ~}$

Table 10. Distribution of Maternal KIR With Paternal HLA-C Genotypes

\begin{tabular}{|c|c|c|c|c|c|}
\hline KIR Genotype & $\begin{array}{l}\text { HLA-C } \\
\text { Genotype }\end{array}$ & $\begin{array}{c}\text { Couples With Preeclampsia }(n=100) \\
\text { No. }(\%)\end{array}$ & $\begin{array}{l}\text { Healthy Couples }(n=100) \\
\text { No. (\%) }\end{array}$ & $\begin{array}{l}P \text { Value (Yate } \\
\text { Correction) }\end{array}$ & OR (Cl) \\
\hline \multirow[t]{2}{*}{$A A$} & $\mathrm{C} 1$ or $\mathrm{C} 2$ & 10 & 20 & NS & NA \\
\hline & $\mathrm{C} 1$ and $\mathrm{C} 2$ & 22 & 8 & $0.0100 *$ & 3.24 (1.36-7.69) \\
\hline \multirow[t]{2}{*}{$A B$ or $B B$} & $\mathrm{C} 1$ or $\mathrm{C} 2$ & 37 & 32 & NS & NA \\
\hline & $\mathrm{C} 1$ and $\mathrm{C} 2$ & 31 & 40 & NS & NA \\
\hline
\end{tabular}

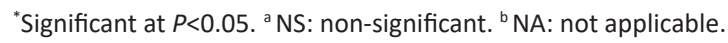

associated with preeclampsia, because of lower activity of the NKs having a high capacity of cytokines, angiogentic and adhesive molecules. Our results supported the hypothesis for maternal KIR2DL1 in combination with paternal $H L A-C 2$ (sensitivity $=79 \%$ ) as well as maternal $A A$ genotype in combination with paternal heterozygosity (specificity $=92 \% ; \mathrm{PPV}=13 \%)$ (Table 11$)$.

The first investigation was done in 2004 by Hiby et al in which maternal KIR and fetal HLA-C genes had been assayed. The authors found that the mothers lacking activating KIRs were more at risk of preeclampsia (27). Yu et al found that in Han Chinese, mothers with KIR $A$ haplotype ( $A A$ genotype) (the haplotype consisting inhibitory KIRs) were more at risk of preeclampsia (28). Another study on Han Chinese showed that lack of activating KIRs is associated with preeclampsia (29), a condition occurring in $A A$ patients. As described by Moffett et al in a commentary, risk of preeclampsia was higher if HLA-C2 of trophoblast was derived from paternal side than of the maternal (30).

All the 3 above studies had assayed maternal KIR and fetal HLA-C at the time of pregnancy, but we assayed paternal HLA-C instead of the fetal. This novelty of our work for preeclampsia enables us to predict preeclampsia before pregnancy. This approach can be used in cohort studies in future. This novelty has also been used in another study by Hiby et al for prediction of infant birth weight (31) and recurrent miscarriage (32).

Activating interactions result in activation of the UNKs having high capacity of cytokines, adhesive and angiogenic factors. These factors are necessary for implantation, arterial remodeling and placentation. Failure in these processes results in insufficient blood supply to fetus and hence preeclampsia (33). Interferon gamma (IFNgamma) required for induction of apoptosis is necessary for implantation and early placentation $(34,35)$ (of course, not pathologic apoptosis). As well, vascular endothelial growth factor (VEGF) is an angiogenic factor necessary for ovulation, implantation and placentation $(36,37)$. Endometrial scratching have recently been used to induce such factors through inducing an artificial inflammation $(38,39)$. All this evidence provides us with a multidimensional approach to pregnancy and reproduction complications. In the present study our approach was immunogenetic.

We had some limitations in our study. First, we could not recognize the number of copies of KIR genes via PCR-SSP; second, we could not recognize the exact subtypes of the genotypes (40); and third, lack of fetal genetic evaluations. Although this study was done as a case-control study, found sensitivities and specificities (Table 11) can be used in cohort and predictive approaches. 
Table 11. Medical Diagnosis Accuracy of the Significant Findings

\begin{tabular}{|c|c|c|c|c|c|c|c|c|}
\hline \multirow{2}{*}{ Significant Findings } & \multirow{2}{*}{$\begin{array}{l}\text { Couples With } \\
\text { Preeclampsia } \\
(n=100) \text { No. }(\%)\end{array}$} & \multirow{2}{*}{$\begin{array}{l}\text { Healthy Couples } \\
(n=100) \text { No. }(\%)\end{array}$} & \multirow{2}{*}{$\begin{array}{c}P \text { Value (Yate } \\
\text { Correction) }\end{array}$} & \multirow{2}{*}{ OR (Cl) } & \multicolumn{3}{|c|}{ Medical Diagnosis Accuracy \% (Cl) } & \multirow{2}{*}{ Accuracy } \\
\hline & & & & & Sensitivity & Specificity & PPV & \\
\hline $\begin{array}{l}\text { Maternal-2DL2/3+ } \\
\text { Maternal-Cla }\end{array}$ & 67 & 82 & 0.0231 & $0.44(0.23-0.86)$ & $82 \%( \pm 6 \%)$ & $33 \%( \pm 6 \%)$ & $9 \%( \pm 1 \%)$ & $57 \%$ \\
\hline Maternal C1 & 67 & 82 & 0.0231 & $0.44(0.23-0.86)$ & $82 \%( \pm 6 \%)$ & $33 \%( \pm 6 \%)$ & $9 \%( \pm 1 \%)$ & $57 \%$ \\
\hline Maternal C2C2 & 33 & 18 & 0.0231 & $2.24(1.16-4.33)$ & $33 \%( \pm 6 \%)$ & $82 \%( \pm 6 \%)$ & $9 \%( \pm 1 \%)$ & $57 \%$ \\
\hline $\begin{array}{l}\text { Maternal-2DL1+ } \\
\text { Paternal-C2 }\end{array}$ & 79 & 64 & 0.0406 & $2.02(1.07-3.81)$ & $79 \%$ ( $\pm 6 \%)$ & $36 \%( \pm 6 \%)$ & $6 \%( \pm 1 \%)$ & $57 \%$ \\
\hline $\begin{array}{l}\text { Maternal-AA+ } \\
\text { Paternal-C1/C2 }\end{array}$ & 22 & 8 & 0.0100 & $3.24(1.36-7.69)$ & $22 \%( \pm 6 \%)$ & $92 \%( \pm 6 \%)$ & $13 \%( \pm 1 \%)$ & $57 \%$ \\
\hline $\begin{array}{l}\text { Maternal-C1/C2+ } \\
\text { Paternal-C1C2 }\end{array}$ & 30 & 16 & 0.0289 & $2.25(1.13-4.46)$ & $30 \%( \pm 6 \%)$ & $84 \%( \pm 6 \%)$ & $9 \%( \pm 1 \%)$ & $57 \%$ \\
\hline
\end{tabular}

${ }^{a}$ First and second rows show protecting effect $(O R<1)$. Hence their sensitivities, specificities, PPVs and accuracies are based on this.

\section{Conclusions}

The inhibitory maternal-paternal combinations KIR2DL1+HLA-C2 and AA+HLA-C1C2 seem to be more associated with preeclampsia. The first combination was more sensitive and the second one was more specific. The main conclusion of the present study was prediction of preeclampsia with help of maternal KIR typing and parental $H L A-C$ typing. Further studies on this hypothesis are necessary in other populations, because approving such hypotheses requires a meta-analysis.

\section{Conflict of Interests}

There is no conflict of interests. The named kits were used because of their previous validation and so there is no commercial interests.

\section{Ethical Issues}

The study was approved by the Ethics Committee of Lorestan University of Medical Sciences with registration number "lums.rec.1394,10". Written consent was obtained from all the participants.

\section{Financial Support}

This study was supported by Lorestan University of Medical Sciences with the ethics registration number "lums.rec.1394,10".

\section{References}

1. Chrelias G, Makris G-M, Papanota A-M, Spathis A, Salamalekis G, Sergentanis TN, et al. Serum inhibin and leptin: Risk factors for pre-eclampsia? Clinica Chimica Acta 2016; 463: 84-7. doi: 10.1016/j.cca.2016.10.013

2. Ahmadi SAY, Shahsavar F, Akbari S. A Review on Controversies about the Role of Immune and Inflammatory Systems in Implantation Process and Durability of Pregnancy. International Journal of Women's Health and Reproduction Sciences 2016; 4: 96-102.

3. Penman BS, Moffett A, Chazara O, Gupta S, Parham P. Reproduction, infection and killer-cell immunoglobulinlike receptor haplotype evolution. Immunogenetics 2016; 68: 755-64

4. Ashouri E, Norman PJ, Guethlein LA, Han AS, NematGorgani N, Norberg SJ, et al. HLA class I variation in Iranian Lur and Kurd populations: high haplotype and allotype diversity with an abundance of KIR ligands. HLA 2016; 88: 87-99. doi: 10.1111/tan.12852

5. Middleton D, Meenagh A, Serrano-Vela JI, Moscoso J, Arnaiz-Villen A. Different evolution of inhibitory and activating killer immunoglobulin receptors (KIR) in worldwide human populations. The Open Immunology Journal 2008; 1.

6. Mousavi T, Shahsavar F, Farnia P, Tajik N, Soofi M. Study of KIR expression and HLA ligands in CD56+ lymphocytes of drug resistant tuberculosis patients. Iran J Allergy Asthma Immunol 2011; 10: 189-94. doi: 010.03/ijaai.189194

7. Ghanadi K, Shayanrad B, Ahmadi SA, Shahsavar F, Eliasy $\mathrm{H}$. Colorectal cancer and the KIR genes in the human genome: A meta-analysis. Genom Data 2016; 10: 118-26. doi: 10.1016/j.gdata.2016.10.010

8. Gomez-Casado E, Martinez-Laso J, Castro M, Morales P, Trapaga J, Berciano M, et al. Detection of HLA-E and-G DNA alleles for population and disease studies. Cellular and Molecular Life Sciences CMLS 1999; 56: 356-62.

9. Arnaiz-Villena A, Morales P, Gomez-Casado E, Castro MJ, Varela P, Rojo-Amigo R, et al. Evolution of MHC-G in primates: a different kind of molecule for each group of species. Journal of reproductive immunology 1999; 43: 11125. doi: 10.1016/S0165-0378(99)00026-1

10. Alizadeh N, Mosaferi E, Farzadi L, Majidi J, Monfaredan A, Yousefi B, et al. Frequency of null allele of Human Leukocyte Antigen-G (HLA-G) locus in subjects to recurrent miscarriage. International Journal of Reproductive BioMedicine 2016; 14: 459.

11. Fotoohi M, Ghasemi N, Mirghanizadeh SA, Vakili M, Samadi M. Association between HLA-E gene polymorphism and unexplained recurrent spontaneous abortion (RSA) in Iranian women. International Journal of Reproductive BioMedicine 2016; 14: 477.

12. Filippini-Cattaneo G, Bortolotti D, Spalvieri S, Rotola A, Jemec M, Suter T, et al. Soluble HLA-G as a non-invasive biomarker from ovulation to early pregnancy in assisted reproduction. Human Reproduction 2015; 30: 183-.

13. Rizzo R, Lo Monte G, Bortolotti D, Gentili V, Graziano A, Piva I, et al. The impact of HLA-G levels and endometrial NK cells in the uterine flushing from primary and secondary unexplained female infertility. Human Reproduction 2014; 29: 222-.

14. Guo W, Fang L, Li B, Xiao X, Chen S, Wang J, et al. 
Decreased Human Leukocyte Antigen-G Expression by miR-133a Contributes to Impairment of Proinvasion and Proangiogenesis Functions of Decidual NK Cells. Frontiers in Immunology 2017; 8. doi: 10.3389/fimmu.2017.00741

15. Sacks G. Enough! Stop the arguments and get on with the science of natural killer cell testing. Hum Reprod 2015; 30 : 1526-31. doi: 10.1093/humrep/dev096

16. Mousavi T, Poormoghim H, Moradi M, Tajik N, Shahsavar F, Soofi M. Phenotypic study of natural killer cell subsets in ankylosing spondylitis patients. Iran J Allergy Asthma Immunol 2009; 8: 193-8. doi: 08.04/ijaai.193198

17. Clark DA, editor. Mouse is the new woman? Translational research in reproductive immunology. Seminars in immunopathology; 2016: Springer.

18. Würfel W. Reproductive Immunology? More Important than Ever Before. Reproductive Immunology: Open Access 2016. doi: 10.4172/2476-1974.100003

19. Fayazi M, Beigi Boroujeni M, Salehnia M, Khansarinejad B. Ovarian stimulation by exogenous gonadotropin decreases the implantation rate and expression of mouse blastocysts integrins. Iranian Biomedical Journal 2014; 18: 8-15. doi: 10.6091/ibj.1236.2013

20. Samsami Dehaghani A, Doroudchi M, Kalantari T, Pezeshki AM, Ghaderi A. Heterozygosity in CTLA-4 gene and severe preeclampsia. International Journal of Gynecology \& Obstetrics 2005; 88: 19-24. doi: http://dx.doi.org/10.1016/j. ijgo.2004.09.007

21. Shahsavar F, Sabooteh T, Forutani S, Jafarzadeh M, Asadifar B. Comparison of KIR/HLA genotypic analysis in the Lur and Iranian populatins. yafte 2013; 15: 5-14.

22. Shahsavar F, Varzi A-M, Ahmadi SAY. A genomic study on distribution of human leukocyte antigen (HLA)-A and HLA-B alleles in Lak population of Iran. Genomics Data 2017; 11: 3-6. doi: 10.1016/j.gdata.2016.11.012

23. Ashouri E, Ghaderi A, Reed EF, Rajalingam R. A novel duplex SSP-PCR typing method for KIR gene profiling. Tissue Antigens 2009; 74: 62-7. doi: 10.1111/j.13990039.2009.01259.x

24. Solgi G, Ghafari H, Ashouri E, Alimoghdam K, Rajalingam $\mathrm{R}$, Amirzargar A. Comparison of KIR gene content profiles revealed a difference between northern and southern Persians in the distribution of KIR2DS5 and its linked loci. Human immunology 2011; 72: 1079-83.

25. Mercaldo ND, Lau KF, Zhou XH. Confidence intervals for predictive values with an emphasis to case-control studies. Stat Med 2007; 26: 2170-83. doi: 10.1002/sim.2677

26. Kharaghani R, Cheraghi Z, Okhovat Esfahani B, Mohammadian Z, Nooreldinc RS. Prevalence of Preeclampsia and Eclampsia in Iran. Arch Iran Med 2016; 19: 64-71. doi: 0161901/aim.0012

27. Hiby SE, Walker JJ, O'Shaughnessy KM, Redman CW, Carrington M, Trowsdale J, et al. Combinations of maternal KIR and fetal HLA-C genes influence the risk of preeclampsia and reproductive success. The Journal of experimental medicine 2004; 200: 957-65.

28. Yu H, Pan N, Shen Y, Jin S, Zhai J, Qiao D, et al. Interaction of parental KIR and fetal HLA-C genotypes with the risk of preeclampsia. Hypertension in pregnancy 2014; 33: 402-11.
29. Long W, Shi Z, Fan S, Liu L, Lu Y, Guo X, et al. Association of maternal KIR and fetal HLA-C genes with the risk of preeclampsia in the Chinese Han population. Placenta 2015; 36: 433-7. doi: 10.1016/j.placenta.2014.05.008

30. Moffett A, Chazara O, Colucci F, Johnson MH. Variation of maternal KIR and fetal HLA-C genes in reproductive failure: too early for clinical intervention. Reproductive BioMedicine Online 2016.

31. Hiby SE, Apps R, Chazara O, Farrell LE, Magnus P, Trogstad L, et al. Maternal KIR in combination with paternal HLA-C2 regulate human birth weight. J Immunol 2014; 192: 506973. doi: $10.4049 /$ jimmunol.1400577

32. Hiby SE, Regan L, Lo W, Farrell L, Carrington M, Moffett A. Association of maternal killer-cell immunoglobulin-like receptors and parental HLA-C genotypes with recurrent miscarriage. Hum Reprod 2008; 23: 972-6. doi: 10.1093/ humrep/den011

33. Fraser R, Whitley GSJ, Thilaganathan B, Cartwright JE. Decidual natural killer cells regulate vessel stability: implications for impaired spiral artery remodelling. Journal of reproductive immunology 2015; 110: 54-60. doi: 10.1016/j.jri.2015.04.003

34. Chen CP, Piao LZ, Chen XL, Yu JH, Masch R, Schatz F, et al. Expression of Interferon by Decidual Cells and Natural Killer Cells at the Human Implantation Site: Implications for Preeclampsia, Spontaneous Abortion, and Intrauterine Growth Restriction. Reproductive Sciences 2015; 22: 14617. doi: $10.1177 / 1933719115585148$

35. Ahmadi SAY, Tavafi M, Ahmadi PS. A Critical Approach to Administration of Low-Dose Aspirin (LDA) to Improve Implantation Success. International Journal of Women's Health and Reproduction Sciences 2015; 3: 223-4. doi: 10.15296/ijwhr.2015.47

36. Boroujeni MB, Boroujeni NB, Gholami M. The effect of progesterone treatment after ovarian induction on endometrial VEGF gene expression and its receptors in mice at pre-implantation time. Iranian journal of basic medical sciences 2016; 19: 252.

37. Hormozi M, Talebi S, Khorshid HRK, Zarnani AH, Kamali $\mathrm{K}$, Jeddi-Tehrani $\mathrm{M}$, et al. The effect of Setarud $\left(\mathrm{IMOD}^{\mathrm{rx}}\right)$ on angiogenesis in transplanted human ovarian tissue to nude mice. International Journal of Reproductive BioMedicine 2015; 13: 605-14.

38. Lensen S, Sadler L, Farquhar C. Endometrial scratching for subfertility: everyone's doing it. Human reproduction 2016; 31: 1241-4. doi: 10.1093/humrep/dew053

39. Farzadi L, Fakour A, Ghasemzadeh A, Hamdi K, Fard SA, Nouri $M$, et al. The Effect of Local Endometrial Injury and GnRH Agonist on Pregnancy Rate in Patients With Recurrent Implantation Failure. International Journal of Womens Health and Reproduction Sciences 2016; 4: 34-7.

40. Pyo CW, Guethlein LA, Vu Q, Wang R, Abi-Rached L, Norman PJ, et al. Different patterns of evolution in the centromeric and telomeric regions of group $\mathrm{A}$ and B haplotypes of the human killer cell Ig-like receptor locus. PLoS One 2010; 5: e15115. doi: 10.1371/journal. pone. 0015115

(C) 2018 The Author (s); This is an open-access article distributed under the terms of the Creative Commons Attribution License (http://creativecommons.org/licenses/by/4.0), which permits unrestricted use, distribution, and reproduction in any medium, provided the original work is properly cited. 